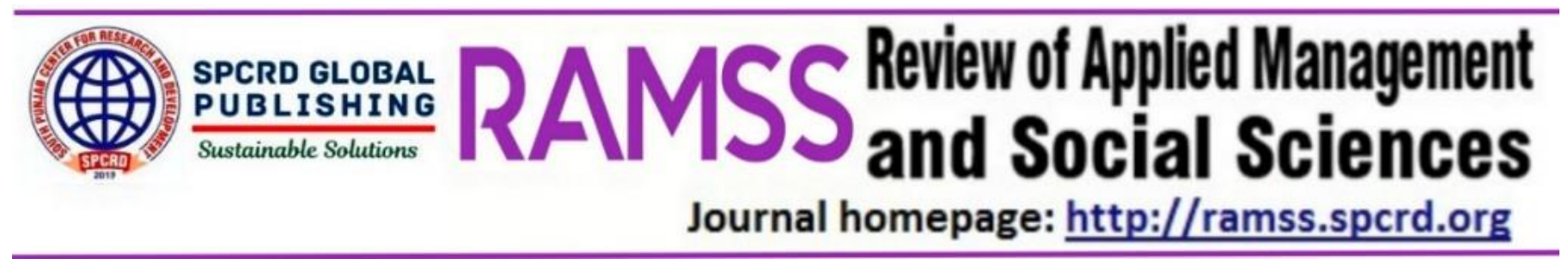

\title{
Analyzing the Factors of Firm Liquidity in Chemical Products and Pharmaceuticals Sector of Pakistan
}

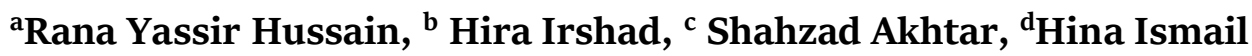 \\ ${ }^{a} P h D$ Scholar, School of Management, Jiangsu University, Jingkou District, Zhenjiang City, Jiangsu Province, China / \\ Lecturer, Department of Economics and Business Administration, Division of Social Sciences, University of Education, \\ Lahore: Yassir.hussain@ue.edu.pk \\ ${ }^{\mathrm{b}}$ School of Economics, Finance and Banking, Universiti Utara Malaysia: hiraharoon48@gmail.com \\ ${ }^{\mathrm{c}}$ Lecturer, Institute of Management Science BZU, Multan: drshahzadakhtar@bzu.edu.pk \\ ${ }^{\mathrm{d}}$ Lecturer, National University of Modern Languages, Multan Campus: hina.ismail@numl.edu.pk
}

\begin{tabular}{|c|c|}
\hline ARTICLE DETAILS & ABSTRACT \\
\hline $\begin{array}{l}\text { History: } \\
\text { Accepted: } 15 \text { December } 2018 \\
\text { Available online: 31December } 2018\end{array}$ & \multirow{5}{*}{$\begin{array}{l}\text { Current study aims at identifying the firm level and country } \\
\text { level determinants of liquidity in listed firms of chemical } \\
\text { products and pharmaceutical sector at PSX. The data sample } \\
\text { consists of } 36 \text { firms over a period of five years ranging from } \\
2013 \text { to } 2017 \text {. A panel OLS regression with robust standard } \\
\text { errors is used to estimate the relationships. Results proved a } \\
\text { positive and significant impact of debt maturity, profitability } \\
\text { and risk on liquidity. Capital structure and asset tangibility } \\
\text { turned out as significant negative influencer of current ratio. } \\
\text { All the three macroeconomic variables had a significant role in } \\
\text { defining liquidity position. However, GDP influenced liquidity } \\
\text { positively but KIBOR and CPI had negative influence. } \\
\text { (C) } 2018 \text { The authors. Published by SPCRD Global Publishing. } \\
\text { This is an open access article under the Creative Commons } \\
\text { Attribution-NonCommercial } 4.0\end{array}$} \\
\hline $\begin{array}{l}\text { Keywords: } \\
\text { Firm, Pharmaceutical, PSX, Pakistan }\end{array}$ & \\
\hline $\begin{array}{l}\text { JEL Classification: } \\
\text { D21, D24, D29 }\end{array}$ & \\
\hline DOI: $10.47067 /$ ramss.v1i1.3 & \\
\hline & \\
\hline
\end{tabular}

Corresponding author's email address: drshahzadakhtar@bzu.edu.pk

\section{Introduction}

The impact Firms are bound to maintain financial solvency in order to meet creditor's claims. A more liquid business gives them more confidence that their claims will be satisfied on time. Therefore, companies must create and maintain liquid reserves in the form of liquid assets. It renders part of the assets as separated from the normal operations and kept as cash or other highly liquid assets to meet the immediate claims. Liquidity management requires a balance of liquid assets that shouldn't be exceeding or subceeding the needed level. There are multiple factors over the years that determine the firm liquidity. Mainly they are categorized as micro and macro determinants of firm liquidity. Micro economic factors are firm specific and macro factors are related to the external environment. Corporations have different motives to have idle cash at their disposal. They use money to carry out daily operations such as that pay salaries to employees, pay dividends to shareholders, purchase of inventory, etc. They are collectively termed as transaction motive. In addition, they keep cash as a 
precautionary measure to take advantage of future growth opportunities if it is difficult to raise instantly and also to manage increased cash flow risk and unreasonable risk (Bates, Kahle\&Stulz, 2006).

The current research takes a cumulative approach as it discusses impact of both micro and macro factors on corporate liquidity in a single framework. The micro factors profitability, risk, capital structure, asset tangibility, firm size and financial expense incurred by the firm. This research also evaluates the impact GDP, KIBOR and inflation on the firm level liquidity. Moreover, this research focus on chemical products and pharmaceuticals sectors of listed Pakistani non-financial firms. It is a promising sector of economy with a balance sheet size of 757 billion rupees at the end of year 2017. The portion of current resources accounted for 294 billion rupees and remaining 463 billion rupees are long term assets. This huge contribution of finances makes it an important area to be studied. This paper is structured as the next section reviews the literature. Third section deal with methodological issues. Results and Discussion secures comes at fourth level and finally paper is concluded.

\section{Literature Review}

Firm liquidity is influenced by multiple micro and macro factors. Total corporate debt has proven to be an important liquidity factor as research experienced in the Dutch non-financial corporations (Bruinshoofd\&Kool, 2002). High corporate debt increases moral and marginal risk financing costs. Uncertainty over access to financial markets is growing in the future. The total debt determined to measure the level of liabilities and their impact was found on liquidity. There is an inverse relationship with size of debtand liquidity (Ferreira \&Vilela, 2004).The company's profitability should be linked to liquidity and moreprofitable firms need to be more liquid. The company's earnings are a source of cash flow. But an annual savings doesn't automatically mean more money despite the fact is that the higher the profit, the more liquid companies are likely to be (Yeboah\& Agyei, 2012).Opler et al. (1999), stated that the companies with the higher access to capital markets, such as large companies having high credit rates tend to maintain a lower liquidity ratio in total non-cash assets.Kim, Mauer \& Sherman (1998) examine the determinants of corporate liquidity. Using a panel from American industrial companies, they found that companies facing higher costs, external funding and variable profits are more likely to have liquidity. In addition, they also found that companies have more liquidity if they expect favorable economic conditions and must have sufficient domestic funds when favorable investment opportunities arise. Isshaq and Bokpin (2009) used dynamic panel model to assess the impact of certain firm level factors on corporate liquidity for 1991 to 2007 in Ghanian listed firms. They found size, networking capital, near liquidity and return on assets as significant determinants of liquidity management. However, total leverage, short term leverage, investment, risk and interest were found to be the insignificant determinants of liquidity.

Gill \& Mathur (2011) employed ANOVA to detect the impact of various variables on firm liquidty. They found significant impact of working capital, firm size, short term debt rate of investment and industrial factors on liquidity. Afza\& Adnan (2007) examined the cash deposits of Pakistani nonfinancial firms between 1985 and 2005. He observed that impact of cash flow, dividend, company size, leverage, growth opportunities and working capital on liquidity. Attari and Raza (2012) studied manufacturing sectors and observed the relationship between size, cash conversion cycle and profitability.The variables like GDP, inflation, short-term rate and government deficit should play a fundamental role in determining corporate liquidity since country specific factors influence all firms. There is an abundance of research that discusses the role of various macroeconomic factors that predict the firm liquidity in banking sector but it is sparse in case of non-financial firms. Chen \& Mahajan 
(2010), took data of 45 countries during 1994 to 2005. They proved a significant impact of GDP, inflation, real interest rate and financial deficit on liquidity of non-financial firms after controlling for endogeneity issues through dynamic panel model.Assfaw (2019) found that firm size, firm growth, GDP and inflation are significant predictors of firm liquidity. Ha \& Phan (2018) studied the size, risk, equity ratio, loan ratio, GDP growth rate has a significant negative impact on liquidity. Whereas, return on equity had a positive impact on liquidity Vietnam. Yana (2018) observed that firm specific variable and macroeconomic variables have an impact on firm liquidity in Bajaj Auto Company during 2011 to 2015 . On the basis of above literature, following hypothesis are proposed:

$\mathrm{H} 1=$ Microeconomic factors have a significant impact on firm liquidity. $\mathrm{H} 2=$ Macroeconomic factors have a significant impact on firm liquidity.

\section{Data and Methodology}

The five year microeconomic data for chemical and pharmaceutical industry is taken from the financial statement analysis (FSA) published by the State Bank of Pakistan (SBP) over a period from 2013 to 2107. The panel data sample consists of 36 firms listed on Pakistan Stock Exchange (PSX) out of 43 firms. Eligibility of firms to be considered as part of final sample is based on their continuous working and listing on the PSX. Firms with missing values is also dropped from the final selection. The macro economic data relating to gross domestic product (GDP), Karachi interbank offer rate (KIBOR) and inflation is taken from the official website of ministry of finance (MOF). The variables, their notations and measurement techniques is given in table 1 below:

\section{Table 1 Variable, notations and measurement technique}

\begin{tabular}{llll}
\hline No & Variable & Notations & Measurement \\
\hline & & & \\
1 & Liquidity & LIQ & Current assets scaled by current liabilities \\
2 & Debt Maturity & DMR & Long term debt scaled by total debt \\
3 & Profitability & ROA & Net income divided by total assets \\
4 & Risk & SDROA & Standard deviation of return on assets \\
5 & Capital Structure & CS & Total equity divided by total debt \\
6 & Asset Tangibility & AT & Fixed assets divided by total assets \\
7 & Size & lnSIZE & Natural log of total assets \\
8 & Financial expense & lnFE & Natural log of financial expenses \\
9 & Economic Growth & GDP & Extracted from website of ministry of finance \\
10 & Interest Rate & KIBOR & Extracted from website of ministry of finance \\
11 & Inflation & CPI & Extracted from website of ministry of finance \\
\hline
\end{tabular}

The standard deviation of return on assets is calculated by collecting the ROA data five year before the study period. In this study we will use multivariate panel ordinary least square (OLS) to determine the impact of independent variables on the dependent variables. The basic econometric models are presented in following equations:

$$
\begin{gathered}
\text { LIQi, }=\alpha+\beta 1(D M R i, t)+\beta 2(R O A i, t)+\beta 3(S D R O A i, t)+\beta 4(C S i, t)+\beta 4(A T i, t)+ \\
\beta 4(\operatorname{lnSIZEi}, t)+\beta 4(\ln F E i, t)+\varepsilon t \\
L I Q i, t=\alpha+\beta 1(D M R i, t)+\beta 2(R O A i, t)+\beta 3(\text { SDROAi, } t)+\beta 4(C S i, t)+\beta 4(A T i, t)+
\end{gathered}
$$




$$
\begin{aligned}
& \beta 4(\operatorname{lnSIZEi}, t)+\beta 4(\ln F E i, t)+\beta 4(G D P i, t)+\varepsilon t \\
& L I Q i, t=\alpha+\beta 1(D M R i, t)+\beta 2(R O A i, t)+\beta 3(S D R O A i, t)+\beta 4(C S i, t)+\beta 4(A T i, t)+ \\
& \beta 4(\operatorname{lnSIZEi} i, t)+\beta 4(\ln F E i, t)+\beta 4(\text { KIBOR } i, t)+\varepsilon t \\
& L I Q i, t=\alpha+\beta 1(D M R i, t)+\beta 2(R O A i, t)+\beta 3(S D R O A i, t)+\beta 4(C S i, t)+\beta 4(A T i, t)+ \\
& \beta 4(\operatorname{lnSIZEi}, t)+\beta 4(\ln F E i, t)+\beta 4(C P I i, t)+\varepsilon t
\end{aligned}
$$

Where, LIQ stand for liquidity, DMR for debt maturity ratio, ROA for return on assets (profitability), SDROA for standard deviation of return on assets (risk), CS for capital structure, AT for asset tangibility, lnSIZE for firm size and lnFE for financial expenditure. The macro economic variables include GDP for gross domestic product, KIBOR for Karachi interbank offer rate and CPI (consumer price index) for inflation. The notation $\alpha, \beta$ and $\varepsilon t$ represent intercept, coefficient and error term of the regression equation.

\section{Results and Discussion}

The results for this research are reported in the following tables. This section involves description of variables, correlation analysis and tests for multicollinearity detection. Four different models have been developed for the data analysis purpose. Each model is run with robust standard errors to tackle the heterogeneity problem.

\section{Table 2 Descriptive Statistics}

\begin{tabular}{lllll}
\hline Variable & Mean & Std Dev & Minimum & Maximum \\
\hline LIQ & 1.616 & 1.262 & .007 & 6.701 \\
DMR & 0.171 & 0.179 & 0 & 0.898 \\
ROA & 7.537 & 15.175 & -72.72 & 67.590 \\
SDROA & 8.145 & 7.971 & 0.624 & 45.322 \\
CS & 1.467 & 4.581 & -3.745 & 52.689 \\
AT & 0.507 & 0.248 & 0.005 & 0.984 \\
lnSIZE & 14.822 & 1.927 & 10.805 & 18.763 \\
lnFE & 9.969 & 2.693 & 1.099 & 15.354 \\
GDP & 4.344 & 0.555 & 3.650 & 5.300 \\
KIBOR & 8.022 & 1.789 & 6.440 & 10.480 \\
CPI & 4.988 & 2.156 & 3.190 & 9.180 \\
\hline
\end{tabular}

Table 2 describes the statistical nature of data titled as descriptive statistics. Overall data is fairly within acceptable range. Liquidity has a mean value of 1.61 with a standard deviation of 1.26. Debt maturity ratio has a mean value of 17 percent. It describes the contribution of long term debt among total debt. It reflects that on average, proportion of long term debt is much smaller as compared to the total debt. Firm risk represented by SDROA has a mean value of 8.14 and a standard variation of 7.97. Capital Structure has a mean value of 1.46 with a standard deviation of 4.58. Average value of asset tangibility describes that on average proportion of fixed assets in total assets is slightly above fifty percent. It has 24.8 percent variation among firms in the study sample. Average logarithmic value for financial expenditures is 9.96 and it can vary up to 2.69. The gross domestic product in the country on average is 4.344 percent during the study period and it fluctuated by 0.55 percent. Similarly, the 
Karachi interbank offer rate (KIBOR) had an average of 8.02 and with a standard variation of 1.78 . Inflation index on average stood at 4.98 and it varied a rate of 2.15 percent during this period.

Table 3 Correlations

\begin{tabular}{llllllllllll}
\hline & LIQ & DMR & ROA & SDROA & CS & AT & lnSIZE & $\operatorname{lnFE}$ & GDP & KIBOR & CPI \\
\hline LIQ & 1 & & & & & & & & & & \\
DMR & 0.01 & 1 & & & & & & & & & \\
ROA & 0.27 & -0.03 & 1 & & & & & & & & \\
SDROA & -0.10 & -0.17 & -0.04 & 1 & & & & & & & \\
CS & -0.15 & 0.00 & 0.00 & 0.13 & 1 & & & & & & \\
AT & -0.68 & 0.36 & -0.23 & 0.20 & 0.03 & 1 & & & & & \\
LnSIZE & -0.04 & 0.14 & 0.34 & -0.25 & 0.01 & -0.03 & 1 & & & & \\
LnFE & -0.18 & 0.30 & 0.24 & -0.24 & 0.15 & 0.14 & 0.78 & 1 & & & \\
GDP & 0.03 & -0.12 & -0.02 & -0.05 & 0.05 & -0.01 & 0.04 & -0.04 & 1 & & \\
KIBOR & -0.03 & 0.10 & 0.07 & 0.02 & - & -0.01 & -0.04 & 0.03 & -0.78 & 1 & \\
CPI & -0.04 & 0.05 & 0.11 & 0.01 & -0.04 & -0.02 & -0.03 & 0.03 & -0.52 & 0.72 & 1 \\
\hline
\end{tabular}

Table 4 Variance Inflation Factor (VIF)

\begin{tabular}{lll}
\hline Variable & VIF & $1 /$ VIF \\
\hline DMR & 1.34 & 0.7475 \\
ROA & 1.24 & 0.8054 \\
SDROA & 1.26 & 0.7927 \\
CS & 1.12 & 0.8956 \\
AT & 1.42 & 0.7057 \\
LnSIZE & 3.12 & 0.3203 \\
LnFE & 3.33 & 0.3003 \\
GDP & 2.67 & 0.3739 \\
KIBOR & 4.06 & 0.2461 \\
CPI & 2.15 & 0.4642 \\
Mean & 2.17 & \\
\hline
\end{tabular}

The table 3 represents the degree of correlations among study variables. The degree of correlations give a hint to understand the possible multicollinearity problem among the variables especially if the values of correlation coefficients are higher than fifty percent in either direction. To further investigate the issue of multicollinearity we performed variance inflation factor analysis. A value of VIF greater than 10 poses a threat of multicollinearity among study variables. However, none of the variables in our analysis had a VIF value greater than the cutoff point. It refers to the data normality as for as VIF reports.

Table 5 reports the results for panel OLS with robust standard errors for all the models developed. This table states that debt maturity ratio (DMR) is a positive and significant determinant of liquidity in all the models developed. Firm profitability also has a positive and significant impact on liquidity of firms included in chemical and pharmaceuticals industry. The idiosyncratic risk also has a positive influence on liquidity in all model at ten percent level of significance except model 1 which 
excludes any macroeconomic variables. Capital structure has negative association with firm liquidity at ten percent level of significance. Proportion of fixed assets in total assets is strong negative predictor of liquidity. It refers that if the proportion of fixed assets increases in asset structure or we can say that the maturity structure of assets increases the liquidity position of the firm worsens. Company size and financial expenditure are negative determinants of liquidity. In case of macroeconomic determinants, gross domestic product (GDP) has a positive and significant impact on firm liquidity as reported under model 2. It refers that the economic growth in the country improves the corporate liquidity in this sector of firms. We took Karachi interbank offer rate as proxy for cost of external financing or prevailing base interest rates in the country. The model 3 reports its impact on liquidity as significant negative predictor. It refers that if interest rates in the country increase as they are based on KIBOR, the liquidity position of the firms worsens. Finally, the impact of inflation is reported in table 4 represented by consumer price index (CPI). Its results are similar to the KIBOR. Inflation has a significant negative impact on the corporate liquidity. We also employed Breusch Pagan (1979) test to capture heterogeneity. Results for found significant in all the models, confirming the non-homogeneity which led us to run the regression with robust standard errors.

\section{Table 5 Panel OLS with robust standard errors}

\begin{tabular}{lllll}
\hline & Model 1 & Model 2 & Model 3 & Model 4 \\
\hline Cons & $3.934(0.645)^{* * *}$ & $3.131(0.648)^{* * *}$ & $4.724(0.739)^{* * *}$ & $4.405(0.665)^{* * *}$ \\
DMR & $2.699(0.459)^{* * *}$ & $2.791(0.443)^{* * *}$ & $2.796(0.444)^{* * *}$ & $2.752(0.436)^{* * *}$ \\
ROA & $0.013(0.004)^{* * *}$ & $0.013(0.004)^{* * *}$ & $0.013(0.004)^{* * *}$ & $0.014(0.004)^{* * *}$ \\
SDROA & $0.017(0.105)$ & $0.018(0.010)^{*}$ & $0.018(0.010)^{*}$ & $0.017(0.010)^{*}$ \\
CS & $-0.032(0.018)^{*}$ & $-0.034(0.019)^{*}$ & $-0.036(0.019)^{*}$ & $-0.034(0.018)^{*}$ \\
AT & $-3.958(0.339)^{* * *}$ & $-4.01(0.343)^{* * *}$ & $-4.01(0.340)^{* * *}$ & $-3.99(0.339)^{* * *}$ \\
& & & & \\
LnSIZE & $-0.011(0.056)$ & $-0.027(0.058)$ & $-0.029(0.057)$ & $-0.028(0.056)$ \\
LnFE & $-0.080(0.048)^{*}$ & $-0.069(0.049)$ & $-0.068(0.049)$ & $-0.070(0.049)$ \\
GDP & & $0.212(0.113)^{*}$ & & \\
KIBOR & & & $-0.079(0.032)^{* *}$ & \\
CPI & & & & $-0.064(0.025)^{* *}$ \\
R-square & 0.62 & 0.63 & 0.63 & 0.63 \\
F-stat (PV) & $42.44^{* * *}$ & $38.20^{* * *}$ & $38.58^{* * *}$ & $37.75^{* * *}$ \\
Breusch Pagan & $30.23^{* *}$ & $29.05^{* * *}$ & $29.74^{* * *}$ & $29.11^{* * *}$ \\
Test & & & & \\
\hline
\end{tabular}

Note: Values in the parenthesis are robust standard errors. The signs ***, **, * show 1\%, 5\% and 10\% level of significance, respectively

\section{Conclusion}

Firm liquidity is essential for its smooth operations. An illiquid business finds it difficult to meet its payment obligation and also to meet regular expenses. This research has been conducted to estimate the factors that may hinder or boost the availability of liquid assets. Both micro and macro aspects are tested on a sample of firms categorized in chemical and pharmaceutical sector. Micro factors include debt maturity, profitability, risk, asset tangibility, capital structure, size and financial expenditure. Whereas macroeconomic factors studied include economic growth measured through GDP, Karachi interbank offer rate (KIBOR) and inflation measured through consumer price index (CPI). Among microeconomic factors, debt maturity ratio, profitability and risk were positive and significant 
predictors of firm liquidity. Capital structure and asset tangibility turned out to be negative and significant predictors of liquidity.Firm size and financial expenses were negative but insignificant predictors of liquidity. For macroeconomic variables GDP had a positive influence on liquidity whereas, KIBOR and CPI influenced liquidity negatively. This research is important for investors, businesses, policymakers and academicians as well. It also has limitations, as it is confined to only one sector and sample is limited.

\section{References}

Afza, T., \& Adnan, S. M. (2007). Determinants of corporate cash holdings: A case study of Pakistan. Proceedings of Singapore Economic Review Conference (SERC) 2007, August 01-04, Organized by Singapore Economics Review and the University of Manchester (Brooks World Poverty Institute), Singapore 164-165.

Assfaw, A. M. (2019). Firm-Specific and Macroeconomic Determinants of Banks Liquidity: Empirical Investigation from Ethiopian Private Commercial Banks. Journal of Accounting, Finance and Auditing Studies, 5(2), 123-145.

Attari, M. A., \& Raza, K. (2012). The optimal relationship of cash conversion cycle with firm size and profitability. International Journal of Academic Research in Business and Social Sciences, 2(4), 189.

Basir, N. L. M. (2018). Journal of Bajaj Auto.

Bates, T. W., Kahle, K. M., \&Stulz, R. M. (2009). Why do US firms hold so much more cash than they used to?. The journal of finance, 64(5), 1985-2021.

Breusch, T.S. and A.R. Pagan, (1979). A simple test for heteroscedasticity and random coefficient variation.Econometrica 47, 1287- 1294 .

Bruinshoofd, A., \& Kool, C. J. (2002). The determinants of corporate liquidity in the Netherlands

Chen, N., \& Mahajan, A. (2010). Effects of macroeconomic conditions on corporate liquidityinternational evidence. International Research Journal of Finance and Economics, 35(35), 112129.

Ferreira, M. A., \&Vilela, A. S. (2004). Why do firms hold cash? Evidence from EMU countries. European Financial Management, 10(2), 295-319.

Gill, A., \& Mathur, N. (2011) , Factors that Affect Potential Growth of Canadian Firms, Journal of Applied Finance \& Banking, 1(4), 107-123.

Ha, N. T. T., \& Phan, G. Q. (2018). The impact of funding liquidity on risk-taking behaviour of Vietnamese banks: Approaching by Z-Score measure. International Journal of Economics and Financial Issues, 8(3), 29.

Isshaq, Z. and AlufarBokpin, G. (2009), Corporate liquidity management of listed firms in Ghana, AsiaPacific Journal of Business Administration, 1(2), 189-198.

Kim, C. S., Mauer, D. C., \& Sherman, A. E. (1998). The determinants of corporate liquidity: Theory and evidence. Journal of financial and quantitative analysis, 33(3), 335-359.

Opler, T., Pinkowitz, L., Stulz, R., \& Williamson, R. (1999). The determinants and implications of corporate cash holdings. Journal of financial economics, 52(1), 3-46.

Rizwan, M. F. (2015). Determinants of corporate cash holdings and its implications: evidence from Pakistan's corporate sector (Doctoral dissertation, Mohammad Ali Jinnah University Islamabad).

Yeboah, B., \& Agyei, S. K. (2012). Working capital management and cash holdings of banks in Ghana. European Journal of Business and management, 4(13), 120-130. 